\title{
While shoot herbivory mitigates, root herbivory exacerbates eutrophication's impact on diversity in a grassland model
}

Running head: Impact of root herbivory on grasslands

Michael Crawford ${ }^{1,4 *}$, Ulrike E. Schlägel ${ }^{1}$, Felix May ${ }^{2}$, Susanne Wurst ${ }^{3}$, Volker Grimm ${ }^{4,1,6}$, Florian Jeltsch ${ }^{1,5}$

${ }^{1}$ University of Potsdam, Department of Plant Ecology and Nature Conservation, Institute of 10 Biochemistry and Biology, Potsdam, Germany

11 2Leuphana University Lüneburg, Methodology Center, Lüneburg

$12{ }^{3}$ Freie Universität, Functional Biodiversity, Dahlem Centre of Plant Sciences, Institute of

13 Biology, Berlin, Germany

$14{ }^{4}$ Helmholtz-Centre for Environmental Research - UFZ, Department of Ecological Modelling, 15 Leipzig, Germany

$16{ }^{5}$ Berlin-Brandenburg Institute of Advanced Biodiversity Research (BBIB), Berlin, Germany

$17{ }^{6}$ German Centre for Integrative Biodiversity Research (iDiv) Halle-Jena-Leipzig, Biodiversity

18 Synthesis, Leipzig, Germany

*Corresponding author:

Michael Crawford

University of Potsdam

Institute of Biochemistry and Biology

Department of Plant Ecology and Nature Conservation

Am Mühlenberg 3

14476 Potsdam

Germany

E: mscrawfor@gmail.com

T: +49 15222090117

Ulrike E. Schlägel: ulrike.schlaegel@uni-potsdam.de

Felix May: felix.may@leuphana.de

33 Susanne Wurst: s.wurst@fu-berlin.de

34 Volker Grimm: volker.grimm@ufz.de

35 Florian Jeltsch: jeltsch@uni-potsdam.de 
Eutrophication is widespread throughout grassland systems and expected to increase

38 during the Anthropocene. Trophic interactions, like aboveground herbivory, have been shown to

39 mitigate its effect on plant diversity. Belowground herbivory may also impact these habitats'

40 response to eutrophication, but the direction of its influence is much less understood, and likely

41 to depend on factors such as the herbivores' preference for dominant species and the symmetry

42 of belowground competition. If preferential towards the dominant, fastest growing species, root

43 herbivores may reduce these species' relative fitness and support diversity during eutrophication.

44 However, as plant competition belowground is commonly considered to be symmetric, root

45 herbivores may be less impactful than shoot herbivores because they do not reduce any

46 competitive asymmetry between the dominant and subordinate plants.

To better understand this system, we used an established, two-layer, grassland community model to run a full-factorially designed simulation experiment, crossing the complete removal of aboveground herbivores and belowground herbivores with eutrophication. After 100

50 years of simulation, we analyzed communities' diversity, competition on the individual-level, as

51 well as their resistance and recovery. The model reproduced both observed general effects of eutrophication in grasslands and the short-term trends of specific experiments. We found that belowground herbivores exacerbate the negative influence of eutrophication on Shannon

54 diversity within our model grasslands, while aboveground herbivores mitigate its effect. Indeed, data on individuals' above- and belowground resource uptake reveals that root herbivory reduces resource limitation belowground. As with eutrophication, this shifts competition aboveground.

57 Since shoot competition is asymmetric - with larger, taller individuals gathering disproportionate resources compared to their smaller, shorter counterparts - this shift promotes the exclusion of

59 the smallest species. While increasing the root herbivores' preferences towards dominant species

60 lessens their negative impact, at best they are only mildly advantageous, and they do very little

61 reduce the negative consequences of eutrophication. Because our model's belowground

62 competition is symmetric, we hypothesize that root herbivores may be beneficial when root

63 competition is asymmetric. Future research into belowground herbivory should account for the

64 nature of competition belowground to better understand the herbivores' true influence. 
66 Keywords: Belowground herbivory, belowground competition, aboveground herbivory,

67 aboveground competition, symmetry, eutrophication, grassland, resilience, resistance, recovery,

68 individual-based model

\section{Introduction}

Eutrophication, i.e. excessive nutrient (e.g. $\mathrm{N}$ and $\mathrm{P}$ ) deposition into ecosystems, reduces diversity worldwide and may likely worsen as globalization drives land-use intensification

72 (Vitousek et al. 1997; Lambin et al. 2001; Steffen et al. 2015). In terrestrial ecosystems,

73 grasslands are heavily impacted by eutrophication (Stevens et al. 2004; Dupré et al. 2009;

74 Bobbink et al. 2010; Hautier et al. 2014). Those in central Europe, for example, have seen

75 reductions in plant diversity of $50 \%$ over the last 50 years, mostly attributable to local nutrient

76 input and land use intensification (Wesche et al 2012).

These negative impacts emerge as competitive plant functional types (PFTs) begin to dominate the community (Harpole and Tilman 2007; Hautier et al. 2009). No longer resourcelimited, these species — well adapted to quickly converting nutrients into biomass - rapidly grow

80 to overshadow their smaller neighbors. Their initial superiority is further compounded by the 81 asymmetry inherent in aboveground competition, with taller plants obtaining disproportionately

82 more light than their shorter counterparts (Weiner et al. 1986; DeMalach et al. 2016, 2017;

83 Hautier et al. 2018). This asymmetry is the primary reason trophic interactions are recognized as

84 an important mechanism through which grassland diversity can resist and potentially recover

85 from eutrophication.

Aboveground herbivory tends to inhibit competitive exclusion by reducing the competitive asymmetry between the largest and smallest plants. By disproportionately affecting the largest, fastest growing functional types, aboveground herbivory increases the light available to smaller individuals (Borer et al. 2014). Thus, aboveground herbivory presents a countervailing

90 force that may constrain the species loss due to eutrophication, safeguarding diversity by

91 decreasing the performance of the strongest species (Olff and Ritchie 1998; Anderson et al.

92 2018; Mortensen et al. 2018; but see Borgström et al. 2016). Further, several recent studies have

93 also indicated that trophic interactions such as herbivory can increase the resilience of grasslands

94 to stress through trophic compensation (Thébault and Fontaine 2010; Eisenhauer et al. 2011;

95 Giulia et al. 2015), though not eutrophication per se. 
While the role of aboveground herbivory in mitigating the impact of eutrophication on

97 diversity has been established, the impact of its counterpart belowground is poorly understood

98 (Blossey and Hunt-Joshi 2003). Despite 40-70\% of annual net primary production being

99 belowground (Vogt et al. 1995) and root herbivores likely removing as much, or more, biomass

100 than their foliar cousins (Zvereva and Kozlov 2012; Kozlov and Zvereva 2017), practical

101 obstacles in its research have left belowground herbivory historically "out of sight, out of mind,"

102 (Hunter 2001). The two studies that have investigated root herbivory's role in the response of

103 grassland systems to eutrophication have shown that herbivores compound its effect, further

104 decreasing biodiversity (La Pierre et al. 2014; Borgström et al. 2017).

105 Most recently, Borgström et al. (2017) designed a factorial experiment, crossing the

106 presence of aboveground herbivores, belowground herbivores, and eutrophication. They found

107 that while aboveground herbivory decreased the relative biomass of grasses and thus

108 counteracted the impact of eutrophication, root herbivores consistently decreased diversity,

109 regardless of the other treatments. These results are striking: Above- and belowground herbivory

110 are not equivalent. This highlights the need to investigate the underlying mechanisms behind this

111 difference more deeply. By further developing this understanding, we will improve our ability to

112 predict biodiversity in grassland ecosystems, as well as their response to eutrophication.

113 Some evidence shows belowground herbivores are preferential towards larger root

114 systems, rather than generalist, and that they may reduce these plants' dominance and support

115 diversity (Sonnemann et al. 2012, 2015). Indeed, several studies have shown that belowground

116 herbivores increase diversity, albeit in non-eutrophic systems (De Deyn et al. 2001; Stein et al.

117 2010). However, the mechanisms underlying above- and belowground herbivory may be more

118 complicated than comparing their feeding preferences alone. This is because contrary to plant

119 competition aboveground, belowground resources are most often symmetrically allocated based

120 on plant size (Schwinning and Weiner 1998). Without a competitive asymmetry to equalize, root

121 herbivores are unlikely to foster diversity maintenance (Chesson 2000). By way of analogy, if

122 aboveground competition were not size-asymmetric, size asymmetric herbivory would be less

123 effective in increasing the community's diversity.

124 To summarize, the literature suggests that belowground herbivores do not necessarily

125 mitigate eutrophication, but their effects may hinge on their preference towards competitive

126 species as well as the symmetry of belowground competition. To break down how root herbivory 
127 influences the diversity and resilience of grassland systems — and their reaction to

128 eutrophication - it would be helpful to test in isolation not just the effect of herbivory (above-

129 and belowground) and eutrophication, but also of the belowground herbivores' preferences

130 towards dominant PFTs. These nuances are ripe to be investigated with ecological modeling,

131 which enables researchers to continuously monitor high-resolution variables describing not only

132 the plants' state but also their above- and belowground competitive environment. Further, given

133 that the full extent of eutrophication's influence may only emerge over the long-term (Kidd et al.

134 2017), modeling may provide additional useful insights.

135 In this paper, we extend on the empirical short-term results of Borgström et al. (2017) by

136 implementing their factorial design inside of an established grassland community model. We

137 then parameterize the feeding preferences of the belowground herbivores to reflect a gradient

138 from generalist to preferential. While "generalists" will consume all species equally, proportional

139 to their biomass, "preferential" herbivores will disproportionately focus on the dominant species

140 within the grassland, asymmetrically consuming those species that have larger root systems.

141 We also expand on their work by examining herbivores' impact on the resilience of

142 grasslands to eutrophication. Despite some studies predicting that trophic interactions will

143 increase the stability of ecological systems (Thébault and Fontaine 2010; Eisenhauer et al. 2011;

144 Giulia et al. 2015), no studies have examined how belowground herbivores mediate the response

145 of grasslands to stresses like eutrophication. Therefore, in addition to examining the impact of

146 herbivores on grasslands diversity per se, we also investigate how the removal of herbivores

147 (above- and belowground) impact the resistance and recovery (sensu Hodgson et al. 2015) of

148 these grasslands to eutrophication.

\section{$1493 \quad$ Methods}

We used the individual-based and trait-based, spatially-explicit grassland assembly

151 model, IBC-grass (May et al. 2009), that incorporates above- and belowground herbivory. Since

152 its introduction (May et al. 2009), IBC-grass has been used to investigate numerous aspects of

153 grassland dynamics, from resilience (Weiss and Jeltsch 2015; Radchuck et al. 2019), to species

154 coexistence (Pfestorf et al. 2016; Crawford et al. 2018), and ecotoxicology (Reeg et al. 2017;

155 Reeg et al. 2018). Importantly, Weiss et al. (2014) parameterized the model with data from trait

156 databases and a survey of plant functional types from German grasslands collected through the 
157 Biodiversity Exploratories (Fischer et al. 2010; Pfestorf et al. 2013). With this empirical

158 parameterization the model successfully reproduces, without calibration at the community level, empirically-observed grassland biodiversity patterns (Weiss et al. 2014).

A full description of the model can be found in the ODD (Overview, Design concepts,

161 Details) protocol (Grimm et al. 2010, 2006; Appendix S1). The following is a summary of the model as well as an explanation of our modifications to it.

\subsection{Overview of the IBC-grass model}

IBC-grass simulates local community dynamics on a 141 x 141 cell grid, where each cell corresponds to $1 \mathrm{~cm}^{2}$ (resulting in a roughly $2 \mathrm{~m}^{2}$ grid space) and can hold one plant's stem. Its time step corresponds to one week, and there are 30 weeks per year representing the vegetation period. A plant is characterized by its functional traits and the biomass of its three distinct compartments: aboveground mass, belowground mass, and reproductive mass.

A plant's competitive area is defined by an aboveground and a belowground "zone of influence" (ZOI). The two ZOIs are both circular areas around the plant's stem, from which it acquires either above- or belowground resources (Schwinning and Weiner 1998; Weiner et al. 2001). While the plant's stem is contained within one grid cell, its ZOI can cover many.

173 Belowground, the area of a plant's ZOI is related directly to its root biomass (Appendix S1: Eq.

174 A3a). Aboveground, the area is the product of its aboveground biomass as well as two functional 175 traits, leaf-mass ratio (LMR) and specific leaf area (SLA) (Appendix S1: Eq. A1). The plant's

176 LMR describes its proportion of photosynthetically active (leaf) tissue to the total shoot tissue 177 and its SLA is a constant ratio between leaf mass and ZOI area. In IBC-grass, a plant with a low

178 LMR will generally have a small shoot area, but overshadow its shorter neighbors; a high SLA

179 corresponds to a leaf that is larger and therefore able to gather more aboveground resources, but

180 also less well defended from aboveground herbivory than its lower-SLA counterparts.

When two plants' ZOIs overlap they compete for resources. A cell's aboveground resources

182 correspond to light while its belowground resources - likewise unidimensional — therefore

183 correspond to water and nutrients. The proportion of a cell's resources a plant obtains during

184 competition depends on its competitive abilities and how many other ZOIs overlap the cell.

185 Aboveground competition is size-asymmetric, i.e. the larger plant takes up resources from each

186 contested cell not only in proportion to its competitive ability (measured as the maximum units it 
187 can acquire per week, termed its $\mathrm{g}_{\max }$ ), but also in proportion to its aboveground mass and $\mathrm{LMR}^{-}$

18 1 $^{1}$, reflecting its height advantage over the smaller plants (Appendix S1: Eq. A3b). In other words, 189 aboveground competition disproportionately favors the larger, taller competitor. Belowground

190 competition, however, is size-symmetric, i.e. only their competitive abilities (their $\mathrm{g}_{\max }$ ) are

191 considered (Appendix S1: Eq. A3a).

192 Intraspecific competition is also included in the form of negative-density dependent

193 competition, reflecting species-specific predators or pathogens (May et al. 2009). This density-

194 dependent competition was modeled by decreasing the resource uptake of an individual in

195 proportion to the square-root of the number of conspecifics in its neighborhood ZOI (Appendix

196 S1: Eq. A3c).

197 All grid cells' total resources are kept constant through space and time; only a plant's biotic 198 neighborhood influences the amount of resources available to it at any given time step. When a

199 plant is unable to gather enough resources, it changes its resource allocation between above- and

200 belowground parts, depending on which compartment is more limited (i.e. shoot or root). If

201 resource uptake in either of the two compartments is below a certain threshold, the plant is

202 considered stressed. Each consecutive week a plant is stressed increases its chance of mortality

203 linearly, in addition to a background, stochastic, annual mortality of $20 \%$.

204 The plants are characterized by four sets, or syndromes, of functional traits, a subset of 205 those proposed as the "common core list of plant traits" by Weiher et al. (1999). The first set of

206 traits defines the plant's maximum size $\left(\mathrm{m}_{\max }\right)$, which positively correlates with seed size and 207 negatively correlates with dispersal distance (Eriksson and Jakobsson 1998; Jongejans and 208 Schippers 1999). The second defines the plant's growth form, or leaf to mass ratio (LMR), which 209 describes the plant as either a rosette, erect, or intermediate growth form type. The third set 210 defines its competitive ability, or maximum resource utilization per time step ( $\left.g_{\max }\right)$, and 211 negatively correlates with its stress tolerance (Grime 2001). The fourth trait set describes the 212 plant's grazing response, positively correlating its palatability with its specific leaf area (SLA)

213 (Westoby et al. 2002).

\section{$214 \quad 3.2 \quad$ Aboveground herbivory}

Aboveground grazing events, modelling the herbivory of large mammals, reflect the

216 partial removal of a plant's aboveground biomass. The frequency of grazing is specified by a 
217 constant weekly probability ( $\mathrm{p}_{\text {graz }}$ ) of a grazing event. The grazers tend to act selectively towards

218 certain traits, with a preference for larger, taller individuals exhibiting high SLAs, which

219 corresponds to relatively palatable leaves (Díaz et al. 2001).

$$
s_{\text {graz }}=m_{\text {shoot }} \cdot L M R^{-1} \cdot S L A
$$

eq. 1

The probability for a given individual to be grazed within one week is derived as its

225 the plants (in other words, the susceptibility of the most-susceptible plant). All plants are

226 checked to be grazed in a random order. If a plant is grazed, $50 \%$ of its shoot mass and all of its

227 reproductive mass are removed. The random choice of plants is repeated without replacement

228 until $50 \%$ of the total aboveground biomass on the grid has been removed or the residual

229 biomass is reduced to less than $\left(15 \mathrm{~g} / \mathrm{m}^{2}\right.$, Schwinning and Parsons 1999) what is considered

230 ungrazable. After a pass through the entire plant community, if either of these two end conditions

231 are unmet the process is repeated. This allows a plant individual to be grazed never or several

232 times during one week with a grazing event.

233 In this study, we use a grazing probability of 0.2 per time step, consistent with previous

234 studies using this submodel.

\subsection{Belowground herbivory}

Belowground herbivory was implemented such that each time step some percentage of

237 the extant biomass is removed from each of the plants, with a gradient of preference in root size

238 ranging from generalist to preferential (i.e. disproportionally eating larger root systems). This

239 herbivory algorithm is intended to reflect the influence of belowground, invertebrate herbivores,

240 such as those belonging to the genus Agriotes, one of the most abundant root herbivores in

241 Europe. As this genus generally tends to eat plants with high biomass and growth rates

242 (Sonnemann et al. 2012, 2015), we refrain from explicitly modelling the plants' roots

243 palatability.

244 The feeding need at week $t, n_{t}$, is calculated as a defined percent (feeding rate, $f$ ) of that

245 week's expected root mass, which is estimated by averaging each previous week's total realized 246 root biomass $R_{i}$ for the previous $w$ weeks, 


$$
n_{t}=f \cdot \frac{\sum_{i=t-w}^{t-1} R_{i}}{w}
$$

250 For this analysis, the feeding rate $(f)$ is 0.1 per week, potentially lower than the typical

251 belowground herbivory pressure (Zvereva and Kozlov 2012), but equal to the aboveground

252 herbivory pressure commonly used in IBC-grass. The number of weeks used to estimate the

253 expected root mass, $w$, is 10. Both parameters are held constant in the following analysis.

254 The biomass to be removed from each individual's root mass $\left(g_{i, t}\right)$ is calculated each

255 week as:

$$
g_{i, t}=\left(\frac{r_{i, t}}{R_{t}}\right)^{\alpha} \cdot n_{t}
$$

where $r_{i, t}$ is the expected root mass of individual $i$ in week $t$ and $R_{t}$ is the week's realized total root mass, which may differ from the expected root mass (Appendix S1: Fig. A3). $R_{t}$ differs

261 from $R_{i}$ in eq. 2 in that $R_{i}$ refers to the total realized root biomass on week $i$ (and ranging

262 backwards by $w$ weeks), whereas $R_{t}$ refers to the total realized root biomass on the current week.

263 The parameter $\alpha$ represents the generality of the herbivory; set at $\alpha=1, g_{i, t}$ will equal the

264 plant's root mass $\left(r_{i, t}\right)$ in proportion to the total root mass $\left(R_{t}\right)$ at time $t$. Above $1, \alpha$ will increase

265 the preference of the herbivores to disproportionally prefer large root systems (Sonnemann et al.

266 2013). This parameter is varied from 1 (generalist) to 2 (extremely preferential). If the biomass

267 to be removed from a plant is larger than its total root mass (which may occur, based on the 268 distribution of plant biomasses and $\alpha$ ), the plant is killed and the overshoot biomass remains in 269 the feeding need $\left(n_{t}\right)$, to be removed from other plants.

\subsection{Eutrophication}

Eutrophication was simulated as an increase in belowground resources (BRes) from the

272 baseline resource rate. Therefore, in IBC-grass a eutrophication intensity of 10 would translate to

273 an increase in belowground resources of 10 BRes for the duration of the experiment.

274 Immediately after the experimental period, the belowground resources return to their pre-

275 eutrophication level for 100 simulation years, for the analysis of the plots' recovery. Although 
276 abiotic modifications to natural communities (e.g. nutrient, herbicide, or pesticide addition) will

277 degrade more slowly than is modelled in our present work, we argue that as a first

278 approximation, this simplifying assumption will demonstrate - in principle - how the biotic

279 community will respond to the cessation of these human-caused disturbances. For this analysis

280 we increased the amount of belowground resources by $50 \%$ over their baseline levels (Weiss et

281 al. 2014), increasing from 60 to 90 BRes during the experimental period.

\subsection{Simulation design and experiments}

We implement a full-factorial design mirroring Borgström et al. (2017) inside of IBCgrass. After a burn-in period of 100 simulation-years wherein the communities settle into quasiequilibrium, they are experimentally manipulated through the application of aboveground herbivore exclusion, belowground herbivore exclusion, and eutrophication, fully crossed. Before the experimental treatments begin, all simulations have a moderately-low level of baseline belowground resources (60 resource units) and both above- and belowground herbivory. The belowground herbivory is parameterized along a gradient of preferentiality, such that each community has one of five levels from 1 (generalist) to 2 (very preferential, see Methods: Belowground Herbivory). During the experimental period, aboveground and belowground

292 herbivore exclusion is modelled as the complete elimination of these two submodels. This period 293 lasts for 100 simulation years, long enough for all communities to reach a quasi-equilibrium once 294 again. After the experimental window ends, the presence of above- and belowground herbivores, 295 as well as the level of belowground resources returns to their pre-experiment values and the 296 simulation is left to run for another 100 years, so that the communities' recovery can likewise be examined. Each parameterization is replicated 50 times.

To understand how these three factors (above- and belowground herbivory, and eutrophication) influence the diversity of our model grasslands, we examine the simulated communities' Shannon diversity — which combines the effects of richness and evenness — shortly

301 after the experiment begins and immediately before it concludes. We then investigate the 302 corresponding shifts in the individuals' resource uptake levels (a proxy for competition). To 303 understand the grasslands' resilience dynamics, we also inspect two key resilience metrics (sensu 304 Hodgson et al. 2015), resistance and recovery. Resistance is the magnitude of change some 305 metric (e.g. diversity) undergoes directly after a disturbance. In our case, we were exploring the 
306 effects of eutrophication on diversity with and without above- and belowground herbivory.

307 Experimentally removing the herbivores was thus a diagnostic — or proximate disturbance-

308 meant to reveal the stabilizing effects of herbivory, while the ultimate disturbance of interest was

309 eutrophication. Recovery is the amount of time needed for a system to reach its original state

310 (measured as time to recovery, TTR). Here we explored recovery, with and without

311 eutrophication, after herbivory was reinstated. Recovery necessitates some external seed input,

312 so for the duration of the recovery period we add a modicum of seeds -

31310 seeds $m^{-2}$ PFT $^{-1}$ year $^{-1}$ (Weiss et al. 2014, Reeg et al. 2018) — to reintroduce any species

314 extirpated during the experimental phase. A community is considered to have recovered once its

315 diversity returns to within two standard deviations of the control communities'-no herbivory

316 removal or eutrophication-diversity.

\section{Results}

After 100 years, both eutrophication and the presence of generalist belowground

319 herbivory decrease Shannon diversity, while aboveground herbivory increases it (Fig. 1). A

320 linear model predicting Shannon diversity through the three-way interaction of these variables

321 (Table 1) revealed significant interactions between eutrophication and both above- and

322 belowground herbivory. While aboveground herbivory can partly mitigate the negative impacts

323 of eutrophication on diversity, belowground herbivory exacerbates it. Interestingly, while there

324 was no interaction between above- and belowground herbivory at ambient levels of belowground

325 resources, a significant three-way interaction with eutrophication indicates that — in grasslands

326 with eutrophication - combined above- and belowground herbivory result in a significantly

327 lower Shannon diversity than if there was no interaction present (i.e. their effects were additive).

328 This interaction was larger than the negative effect of belowground alone.

329 Comparing our results to Borgström et al. (2017), the patterns of Pielou's evenness (E)

330 shortly after the experimental period begins (3 years, mirroring Borgström et al. 2017) are

331 broadly concordant (Appendix S2: Fig. 1).

\section{$332 \quad$ Variation with root herbivore preference}

333 We next shift our attention from generalist belowground herbivores to those with

334 increasing preference towards dominant species, by testing a gradient from generalist herbivores 
$335(\alpha=1)$ to those extremely preferential towards large root systems $(\alpha=2)$. We found that

336 increasing the herbivore's preference towards dominant plants increased diversity relative to

337 purely generalist herbivores, but that this effect was insufficient to mitigate the negative effects

338 of eutrophication (Fig. 2). Although in grasslands with ambient resources, very preferential

339 herbivores had no impact on diversity (especially compared to generalist herbivores, which

340 significantly reduced it), eutrophication reduced diversity by threefold the positive impact of

341 preferential herbivores, overshadowing any positive influence of preferential herbivory.

342 Therefore, preferential herbivores, at most, neutrally impact diversity.

343 To understand how preferential herbivory differentially impacted species fitness more

344 deeply, we isolated the dominant PFT from each community with generalist herbivores, defining

345 it to be the PFT with the largest summed root biomass. We then plotted its total root biomass

346 under the gradient of herbivore selectivity, and found that only under ambient belowground

347 resource levels do higher levels of selectivity decrease the total root biomass of the most

348 dominant PFTs in the community (Appendix S2: Fig. 2). Under eutrophication, there is no

349 interaction between that PFT's root biomass and the herbivores' preference for larger root

350 systems.

\section{$351 \quad 4.2 \quad$ Competition on the individuals' level}

352 We also measured the shoot- and root- resource uptake per individual after the

353 experimental period. This measure, the ratio of resource uptake to biomass above- or

354 belowground, is a proxy for competition in each compartment; a high ratio reflects less

355 competition, because the plant is receiving more resources per unit biomass. Lower values,

356 therefore, reflect higher competition wherein few resources are available for the individual to

357 take up. The average ratio between an individual's aboveground resources uptake to it shoot

358 biomass (ARes $: m_{\text {shoot }}$ ) increased in the presence of aboveground herbivores (Fig. 3A). This

359 reflects a decrease in aboveground competition, as the removal of aboveground biomass reduces

360 the number of plants competing for each cells' resources. The introduction of belowground

361 herbivory mitigated this impact, in effect reducing aboveground herbivory's ability to decrease

362 aboveground competition. Eutrophication was even more disruptive to the efficacy of

363 aboveground herbivory, drastically reducing the aboveground resource uptake ratio. This 
364 suggests a large increase in aboveground competition, with plants in eutrophic conditions needing significantly more aboveground biomass to their requisite aboveground resources.

A complementary pattern emerged when inspecting the average root uptake ratio of each community (BRes $: m_{\text {root }}$, Fig. 3B). A high root uptake ratio corresponds to a plant taking up many resources per gram root biomass per time step, reflecting low competitive intensity; plants receive much of the resources they can take up. By contrast, a low uptake ratio means that plants only take up few resources for each gram of their root biomass, reflecting an intense competitive environment. Eutrophic conditions dramatically increased the amount of belowground resources

372 taken up per gram biomass, reflecting a decrease in belowground competition. Likewise,

373 introducing belowground herbivores also decreased belowground competition, as removal of

374 root biomass increased the amount of remaining uncontested resources. Introducing aboveground

375 herbivory had a split effect: Without belowground herbivores, it increased the amount of

376 belowground competition, as the reduction in competition aboveground reverberated into the

377 belowground compartment. With belowground herbivory, however, the two effects cancelled 378 out.

\subsection{Resilience dynamics during eutrophication}

We next investigated the two metrics central to resilience: resistance and recovery (Hodgson et al. 2015) with respect to simulated Shannon-diversity. The diagnostic resistance of

382 our model grasslands, i.e. the response of diversity one year after herbivory was removed, was

383 significantly lower when eutrophication was part of the treatment (Fig. 4). Without

384 eutrophication, there was very little immediate change when belowground herbivores were 385 removed, though aboveground herbivore removal was mildly impactful (Table 2). In other 386 words, eutrophication has a very large immediate effect on how herbivory affected diversity, 387 suggesting that herbivory, and its characteristics, are important modulators of diversity in 388 eutrophic grasslands. The only other strongly significant interaction was between eutrophication 389 and the removal of belowground herbivores, with the removal of root herbivores somewhat 390 mitigating the immediate impact of eutrophication.

391 Recovery was measured as the number of years it takes the community to return to its

392 starting Shannon diversity. As expected, the control scenario - with ambient belowground 393 resources and retaining both compartments' herbivores - was the fastest to recover (Fig. 5), 
394 taking on average two years to fall within two standard deviations of its sample mean for ten

395 years (see Methods: Simulation design and experiments), in line with a normally distributed test

396 of the algorithm (see Appendix S2: Fig. 3). The removal of belowground herbivores increased

397 the TTR compared to the control, but the most damaging experimental configuration-in terms

398 of TTR — was removing aboveground herbivores yet leaving those belowground. In scenarios

399 with eutrophication, the community is quicker to recover if it had a history of belowground

400 herbivory removal, agnostic of aboveground herbivory.

401 Analyzing the impact of the belowground herbivore's preferentiality $(\alpha)$ on the TTR of

402 Shannon diversity, we found that there is little difference between the different herbivory

403 regimes aside from one effect: with ambient belowground resources, the presence of generalist

404 herbivores slightly reduced the time to return compared to the various levels of preferential

405 herbivory, though its median stayed the same (Appendix S2: Fig. 4).

\section{Discussion}

Although the interaction between grassland eutrophication and aboveground herbivory has driven significant interest (Borer et al. 2014, Anderson et al. 2018), the relationship between eutrophication and belowground herbivory has remained largely unexplored. Eutrophication

410 tends to decrease species richness by shifting competition from the belowground compartment to

411 the aboveground compartment, giving a disproportionate advantage to fast growing, tall, species

412 (Bobbink et al. 1998; Hautier 2009; Farrer et al. 2016).

413 In our analysis, using a simulation model we factorially removed above- and

414 belowground herbivores and introduced eutrophication. We found that belowground herbivory

415 compounds the impact of eutrophication on diversity, because like eutrophication it increases the

416 relative proportion of belowground resources to root biomass, resulting in more resources

417 available to the plants' remaining roots. This shifts competition to the aboveground

418 compartment, exacerbating the advantage of largest, fastest growing plants.

419 The clearest evidence of this dynamic within IBC-grass is the relative change in the

420 plants' uptake ratios (Fig. 3). Disregarding above- and belowground herbivory, eutrophication

421 per se increases the amount of belowground resources available to the plants, increasing the

422 resources available per gram of remaining root biomass. This new resource abundance shifts

423 competition aboveground, leading to the competitive exclusion of short and slow-growing 
424 species. These dynamics are consistent with the most contemporary understandings of

425 eutrophication in grasslands (DeMalach et al. 2016, 2017). As these dynamics were not imposed

426 within the model's design (May et al. 2009; Weiss et al. 2014), they can be considered an

427 independent, successful prediction — a strong indicator of structural realism of IBC-grass, defined

428 as its potential to realistically capture the key elements of a grassland's internal organization

429 (Wiegand et al. 2003; Grimm and Berger 2016).

$430 \quad$ Our analysis of belowground herbivory suggests that its main effect is to also increase the

431 amount of resources available to the plants' roots; rather than increasing the amount of nutrients

432 in the soil, root herbivores decrease the amount of biomass present to compete for it. This

433 synthesis of the theory behind eutrophication and the potential impacts of belowground

434 herbivores is new, and has very little footprint within the literature, with only two empirical

435 studies previously examining it.

436 In the first, La Pierre et al. (2014), found that removing belowground herbivores

437 increased plant species evenness after eutrophication events, finding that they behaved as a top-

438 down control on the sub-dominant species within the grassland. Once the herbivores were

439 removed, these species were also able to utilize the new resources and diversity increased. In the

440 second, the relationships between above- and belowground herbivory and eutrophication were

441 also examined empirically by Borgström et al. (2017) — the template for our study's design. They

442 found that both belowground herbivores and eutrophication depress diversity, while

443 aboveground herbivory increases it. Although these general effects are consistent across both our

444 studies, the smaller interactions are not fully consistent. While Borgström et al. (2017) also

445 found that root herbivory generally decreased species evenness, they found that the herbivores'

446 effects were more pronounced with ambient resource levels. As these two experiments represent

447 very different study systems, some discrepancies between them are not surprising. As a

448 simulation model, IBC-grass enables us to observe the diversity patterns of a simplified

449 grassland, emergent from basic ecological assumptions. Since Borgström and colleagues used

450 grassland mesocosms, their results will incorporate nuances endemic to their grassland system.

451 This degree of detail, however, may obscure the larger picture; while models' simplifications

452 inevitably omit some of the more complex interactions embedded in real grasslands,

453 simplification enables us to examine the processes likely general to most grassland ecosystems. 
Several secondary factors confound the direct comparison of the two studies. IBC-grass uses a larger spatial extent and much larger species pool, and its aboveground herbivory is modeled after ungulates rather than invertebrates. Further, while Borgström et al. (2017) could

457 precisely measure the amount of nitrogen added to the soil, in IBC-grass belowground resources

458 are phenomenological and correspond simply to the "resources taken up belowground," and

459 therefore could be water or nutrients. Therefore, it is not surprising that these systems react

460 somewhat differently to our experimental treatments. However, the main effects found in the

461 empirical study could be replicated without fine-tuning the model's parameters: Belowground

462 herbivory and eutrophication generally negatively impact diversity while aboveground herbivory 463 increases it.

\subsection{Root herbivory's influence on symmetric competition for belowground resources}

Setting aside eutrophication per se, given root herbivores' prevalence in grasslands (Kozlov and Zvereva 2017), building a theoretical understanding of their impact is critical to understanding these systems' diversity. There is little consensus on how herbivory belowground could change a grassland's diversity, with studies finding its influence anywhere from negative (Brown and Gange 1989A, 1989B; Fraser and Grime 2001; Körner et al. 2014) to positive (De Deyn 2003; Stein et al. 2010; Borgström et al. 2017), to neutral (Wurst and Rillig 2011). We argue that this variation in root herbivory's effect stems from two processes: The preferentiality of the root herbivores and the (a)symmetry of belowground competition itself. Our results

473 suggest that for root herbivores to positively impact grassland diversity, belowground

474 competition must be asymmetric. When it is not, even very preferential herbivores will likely 475 only neutrally impact diversity.

476 For a resource like light, herbivores reduce the competitive asymmetry between the

477 largest and smallest plants by generating space in the upper canopy, feeding the plants lower to 478 the ground (Borer 2014; Anderson 2018). However, as belowground competition is often

479 symmetric, our results suggest that herbivores will reduce the plants' biomasses without 480 equalizing their competitive fitness. Any decrease in root biomass will only result in an excess of 481 belowground resources per remaining root biomass, thus reducing root competition. As the 482 belowground compartment is no longer limiting, aboveground competition will increase, and 
483 because aboveground competition is asymmetric, its increase will consequently lead to the exclusion of shorter, slower growing species.

To contextualize this result, it helps to compare the mechanisms behind belowground herbivory to those aboveground. Compared to root herbivory, the impact of shoot herbivory is composed of two asymmetries: The largest plants are eaten asymmetrically, but crucially this reduction in the plants' sizes minimizes a competitive asymmetry between large and short individuals. With symmetric belowground competition, by contrast, no such competitive

490 asymmetry exists. Therefore, root herbivores will generally not be as effective in maintaining 491 biodiversity as their aboveground cousins.

492 If belowground competition is symmetric, our results further indicated that even 493 extremely preferential root herbivory may be unable to increase diversity compared to scenarios

494 without root herbivores. This reflects a balance between the positive influence of

495 disproportionately reducing the largest plants' root biomasses and the corresponding increase in

496 aboveground competition. Of course, relative to purely generalist herbivores, even a low degree

497 of feeding preference will increase diversity (Fig. 2). This suggests that if belowground

498 competition happens to asymmetric, it is likely that any preference of the root herbivores towards

499 dominant plant functional types could prove to be a strong mechanism maintaining a grassland's

500 diversity. Given that other empirical analyses of root herbivory suggest that it may stabilize

501 diversity (De Deyn 2003; Stein et al. 2010; Borgström et al. 2017), future research should

502 investigate the possibility of underlying asymmetries in belowground competition within these 503 study systems.

$504 \quad$ That belowground resources are symmetrically allocated has been an important 505 assumption in grassland and forest modeling (Schwinning and Weiner 1998). Although 506 numerous empirical tests have found this to be the case (Casper and Jackson 1997; Weiner 1997;

507 Berntson and Wayne 2000; Blair 2001; Wettberg and Weiner 2003; Cahill and Casper 2003;

508 Lamb 2008), under certain conditions it is likely to be asymmetric as well (Weiner 1990;

509 Rajaniemi 2002, 2003; Rajaniemi et al. 2003, Weiss et al. 2019). Understanding when

510 belowground herbivory is likely to be asymmetric is therefore necessary to fitting our model's

511 results into a broader context.

512 The empirical literature has found that asymmetry in belowground competition is 513 increased when nutrients are patchy in the soil, giving a competitive advantage to larger root 
514 systems that can disproportionately access them (Fransen et al. 2001; Facelli and Facelli 2003;

515 Rajaniemi 2002; Rajaniemi et al. 2003). A model of belowground competition (Raynaud and

516 Leadley 2005) furthered this hypothesis, finding that the symmetry of belowground competition

517 should also depend on how nutrients diffuse in the soil. In wet soils, nutrients will be more

518 diffuse and therefore plant competition will become more dependent on the plants' uptake

519 kinetics, shifting competition towards asymmetry. This hypothesis has been supported by at least

520 one empirical test (Rewald and Leuschner 2009). Belowground competition could also become

521 asymmetric through its vertical dimension (Schenk 2006), with root systems higher to the surface

522 receiving a larger proportion of water and nutrients (van Wijk and Bouten 2001).

523 To summarize, although belowground competition is often more symmetric than

524 aboveground competition, this balance should not be taken for granted. When belowground

525 competition is symmetric, our model indicates that root herbivory will not support diversity and

526 may even substantially decrease it as it shifts competition aboveground, leading less competitive

527 species towards exclusion. Given that even an extreme asymmetry in the feeding preferences of

528 the herbivores did not shift the direction of their influence on coexistence, our results indicate

529 that variation in the empirical literature on root herbivores likely results not from their feeding

530 preferences in isolation, but also from asymmetries in belowground competition.

\section{$531 \quad 5.2 \quad$ Resilience of grassland systems to eutrophication}

Trophic interactions, such as herbivory, are acknowledged as important contributors to the

533 stability of ecological systems through their compensatory effects (Hillebrand et al. 2007; Gruner

534 et al. 2008; Ghedini et al. 2015). To supplement our investigation into the mechanisms through

535 which herbivory influences grasslands' responses to eutrophication, we also measured how

536 above- and belowground herbivory change the resistance and recovery of our model grasslands

537 to eutrophication. Our main findings indicate that the removal of herbivores is relatively mild in

538 its immediate effect on diversity (Fig. 4), and that once the herbivores return diversity follows

539 relatively quickly (Fig. 5).

540 With eutrophication, however, the magnitude of change is much larger. For resistance, as

541 predicted by ecological theory (Hillebrand et al. 2007; Gruner et al. 2008; Kohli et al. 2019) and

542 empirical evidence (Eisenhauer et al. 2011; Post 2013; Ghedini et al. 2015; McSkimming et al.

543 2015), the presence of aboveground herbivory compensates - albeit weakly - for the immediate 
544 effects of a strong eutrophication event (Fig. 4), and over the course of the 100-year treatment,

545 its impact becomes much more influential (Fig. 1). This suggests that a long experimental

546 duration is necessary to understand the full array of interactions forming a grassland's response

547 to eutrophication (Kidd et al. 2017). Further, simulations retaining aboveground herbivores

548 returned to their pre-disturbance state more quickly than those without it (Fig. 5).

549 Belowground herbivory, however, does not neatly dovetail with ecological theory: Indeed,

550 the presence of root herbivory coincides with a reduction in resistance to eutrophication (Fig. 4),

551 as well as a longer time to return (Fig. 5). This is unsurprising, however, given our finding that

552 belowground herbivores tend to exacerbate the dominance of the strongest competitors, unlike

553 their counterparts aboveground. Once established, these plant species will retain their dominance

554 for a long period of time after nutrient addition is halted.

\section{Conclusions}

556 As anthropogenic changes such as eutrophication increasingly stress grassland ecosystems, 557 understanding what aspects of these communities mediate their ability to resist degradation is 558 becoming increasingly important. Trophic interactions between the plant community and their

559 herbivores are one such aspect. Our results suggest that rather than strengthening a plant

560 community's resilience to a eutrophication event, belowground herbivores compound its

561 negative influence on plant diversity and resilience. These results are tightly interlinked with the

562 symmetry of belowground competition and preferences of the herbivores themselves. Future

563 research must investigate how prevalent competitive asymmetries are within the belowground

564 compartment, as they may be a necessary condition for root herbivores to positively influence

565 diversity.

\section{Author contributions}

567 FM developed, with FJ and VG, the original model; MC and FJ formulated the research 568 question; MC performed, with UES and FJ, the analysis and was the lead author; IS and SW 569 added expert knowledge on belowground herbivory; all authors contributed to the interpretation 570 of results and the writing of the manuscript. 


\section{$8 \quad$ Acknowledgements}

572

573

574

575

576

MC, with FJ, were funded by DFG Priority Program 1374, "Infrastructure-BiodiversityExploratories" (DFG-JE 207/5-1). UES was supported by Deutsche Forschungsgemeinschaft in the framework of the BioMove Research Training Group (DFG-GRK 2118/1). SW was funded by the DFG Priority Program 1374, "Infrastructure-Biodiversity-Exploratories" (DFG-WU 603/3-3).

We thank the managers of the three Biodiversity Exploratories and all former managers for their work in maintaining the plot and project infrastructure, Christiane Fischer, Anja Hoeck, and Cornelia Weist for giving support through the central office, and Markus Fischer, Eduard Linsenmair, Dominik Hessenmöller, Daniel Prati, Ingo Schöning, François Buscot, Ernst-Detlef Schulze, Wolfgang W. Weisser and the late Elisabeth Kalkofor for their role in setting up the Biodiversity Exploratories project.

We lastly thank Niv DeMalach for helpful conversations about the interaction of competition and eutrophication that helped to develop this work.

\section{$9 \quad$ References}

Anderson, T. M., D. M. Griffith, J. B. Grace, E. M. Lind, P. B. Adler, L. A. Biederman, D. M. Blumenthal, P. Daleo, J. Firn, N. Hagenah, W. S. Harpole, A. S. MacDougall, R. L. McCulley, S. M. Prober, A. C. Risch, M. Sankaran, M. Schütz, E. W. Seabloom, C. J. Stevens, L. L. Sullivan, P. D. Wragg, and E. T. Borer. 2018. Herbivory and eutrophication mediate grassland plant nutrient responses across a global climatic gradient. Ecology 99:822-831.

Berntson, G. M., and P. M. Wayne. 2000. Characterizing the size dependence of resource acquisition within crowded plant populations. Ecology 81:1072-1085.

Blair, B. 2001. Effect of soil nutrient heterogeneity on the symmetry of belowground competition. Plant Ecology 156:199-203.

Blossey, B., and T. R. Hunt-Joshi. 2003. Belowground Herbivory by Insects: Influence on Plants and Aboveground Herbivores. Annual Review of Entomology 48:521-547.

Bobbink, R., K. Hicks, J. Galloway, T. Spranger, R. Alkemade, M. Ashmore, M. Bustamante, S. Cinderby, E. Davidson, F. Dentener, B. Emmett, J.-W. Erisman, M. Fenn, F. Gilliam, A. Nordin, L. Pardo, and W. De Vries. 2010. Global assessment of nitrogen deposition effects on terrestrial plant diversity: a synthesis. Ecological Applications 20:30-59. 
Bobbink, R., M. Hornung, and J. G. M. Roelofs. 1998. The effects of air-borne nitrogen pollutants on species diversity in natural and semi-natural European vegetation. Journal of Ecology 86:717-738.

Borer, E. T., E. W. Seabloom, D. S. Gruner, W. S. Harpole, H. Hillebrand, E. M. Lind, P. B. Adler, J. Alberti, T. M. Anderson, J. D. Bakker, L. Biederman, D. Blumenthal, C. S. Brown, L. A. Brudvig, Y. M. Buckley, M. Cadotte, C. Chu, E. E. Cleland, M. J. Crawley, P. Daleo, E. I. Damschen, K. F. Davies, N. M. DeCrappeo, G. Du, J. Firn, Y. Hautier, R. W. Heckman, A. Hector, J. HilleRisLambers, O. Iribarne, J. A. Klein, J. M. H. Knops, K. J. La Pierre, A. D. B. Leakey, W. Li, A. S. MacDougall, R. L. McCulley, B. A. Melbourne, C. E. Mitchell, J. L. Moore, B. Mortensen, L. R. O’Halloran, J. L. Orrock, J. Pascual, S. M. Prober, D. A. Pyke, A. C. Risch, M. Schuetz, M. D. Smith, C. J. Stevens, L. L. Sullivan, R. J. Williams, P. D. Wragg, J. P. Wright, and L. H. Yang. 2014. Herbivores and nutrients control grassland plant diversity via light limitation. Nature 508:517-520.

Borgström, P., J. Strengbom, L. Marini, M. Viketoft, and R. Bommarco. 2017. Above- and belowground insect herbivory modifies the response of a grassland plant community to nitrogen eutrophication. Ecology 98:545-554.

Borgström, P., J. Strengbom, M. Viketoft, and R. Bommarco. 2016. Aboveground insect herbivory increases plant competitive asymmetry, while belowground herbivory mitigates the effect. PeerJ 4:e1867.

Brown, V. K., and A. C. Gange. 1989. Differential Effects of Above- and Below-Ground Insect Herbivory during Early Plant Succession. Oikos 54:67.

Brown, V. K., and A. C. Gange. 1989. Herbivory by Soil-Dwelling Insects Depresses Plant Species Richness. Functional Ecology 3:667.

Cahill, Jr., J. F., and B. B. Casper. 2000. Investigating the relationship between neighbor root biomass and belowground competition: field evidence for symmetric competition belowground. Oikos 90:311-320.

Casper, B. B., and R. B. Jackson. 1997. Plant competition underground. Annual Review of Ecology and Systematics 28:545-570.

Chesson, P. 2000. Mechanisms of Maintenance of Species Diversity. Annual Review of Ecology and Systematics 31:343-366.

Crawford, M., F. Jeltsch, F. May, V. Grimm, and U. E. Schlägel. 2018. Intraspecific trait variation increases species diversity in a trait-based grassland model. Oikos 128:441-455.

De Deyn, G. B., C. E. Raaijmakers, H. R. Zoomer, M. P. Berg, P. C. De Ruiter, H. A. Verhoef, T. M. Bezemer, and W. H. Van der Putten. 2003. Soil invertebrate fauna enhances grassland succession and diversity. Nature 422:711-713. 
DeMalach, N., E. Zaady, and R. Kadmon. 2017. Light asymmetry explains the effect of nutrient enrichment on grassland diversity. Ecology Letters 20:60-69.

DeMalach, N., E. Zaady, J. Weiner, and R. Kadmon. 2016. Size asymmetry of resource competition and the structure of plant communities. Journal of Ecology 104:899-910.

Dupré, C., C. J. Stevens, T. Ranke, A. Bleeker, C. Peppler-Lisbach, D. J. G. Gowing, N. B. Dise, E. Dorland, R. Bobbink, and M. Diekmann. 2010. Changes in species richness and composition in European acidic grasslands over the past 70 years: the contribution of cumulative atmospheric nitrogen deposition. Global Change Biology 16:344-357.

Eisenhauer, N., A. Milcu, E. Allan, N. Nitschke, C. Scherber, V. Temperton, A. Weigelt, W. W. Weisser, and S. Scheu. 2011. Impact of above- and below-ground invertebrates on temporal and spatial stability of grassland of different diversity. Journal of Ecology.

Eriksson, O., and A. Jakobsson. 1998. Abundance, distribution and life histories of grassland plants: A comparative study of 81 species. Journal of Ecology 86:922-933.

Facelli, E., and J. M. Facelli. 2002. Soil phosphorus heterogeneity and mycorrhizal symbiosis regulate plant intra-specific competition and size distribution. Oecologia 133:54-61.

Farrer, E. C., and K. N. Suding. 2016. Teasing apart plant community responses to N enrichment: the roles of resource limitation, competition and soil microbes. Ecology Letters 19:1287-1296.

Fischer, M., O. Bossdorf, S. Gockel, F. Hänsel, A. Hemp, D. Hessenmöller, G. Korte, J. Nieschulze, S. Pfeiffer, D. Prati, S. Renner, I. Schöning, U. Schumacher, K. Wells, F. Buscot, E. K. V. Kalko, K. E. Linsenmair, E. D. Schulze, and W. W. Weisser. 2010. Implementing large-scale and long-term functional biodiversity research: The Biodiversity Exploratories. Basic and Applied Ecology 11:473-485.

Fransen, B., H. de Kroon, and F. Berendse. 2001. Soil nutrient heterogeneity alters competitions between two perennial grass species. Ecology 82:2534-2546.

Fraser, L. H., and J. P. Grime. 1999. Interacting effects of herbivory and fertility on a

Grime, J. P. 2001. Plant strategies, vegetation processes, and ecosystem properties. 2nd. ed. Wiley, Chichester, UK. 
Grimm, V., and U. Berger. 2016. Structural realism, emergence, and predictions in nextgeneration ecological modelling: Synthesis from a special issue. Ecological Modelling 326:177-187.

Grimm, V., U. Berger, F. Bastiansen, S. Eliassen, V. Ginot, J. Giske, J. Goss-Custard, T. Grand,

Grimm, V., U. Berger, D. L. DeAngelis, J. G. Polhill, J. Giske, and S. F. Railsback. 2010. The S. K. Heinz, G. Huse, A. Huth, J. U. Jepsen, C. Jørgensen, W. M. Mooij, B. Müller, G. Pe'er, C. Piou, S. F. Railsback, A. M. Robbins, M. M. Robbins, E. Rossmanith, N. Rüger, E. Strand, S. Souissi, R. A. Stillman, R. Vabø, U. Visser, and D. L. DeAngelis. 2006. A standard protocol for describing individual-based and agent-based models. Ecological Modelling 198:115-126.

Gruner, D. S., J. E. Smith, E. W. Seabloom, S. A. Sandin, J. T. Ngai, H. Hillebrand, W. S. Harpole, J. J. Elser, E. E. Cleland, M. E. S. Bracken, E. T. Borer, and B. M. Bolker. 2008. A cross-system synthesis of consumer and nutrient resource control on producer biomass. Ecology Letters 11:740-755.

Harpole, W. S., and D. Tilman. 2007. Grassland species loss resulting from reduced niche dimension. Nature 446:791.

Hautier, Y., P. A. Niklaus, and A. Hector. 2009. Competition for Light Causes Plant Biodiversity

688

Hautier, Y., E. W. Seabloom, E. T. Borer, P. B. Adler, W. S. Harpole, H. Hillebrand, E. M. Lind, A. S. MacDougall, C. J. Stevens, J. D. Bakker, Y. M. Buckley, C. Chu, S. L. Collins, P. Daleo, E. I. Damschen, K. F. Davies, P. A. Fay, J. Firn, D. S. Gruner, V. L. Jin, J. A. Klein, J. M. H. Knops, K. J. La Pierre, W. Li, R. L. McCulley, B. A. Melbourne, J. L. Moore, L. R. O'Halloran, S. M. Prober, A. C. Risch, M. Sankaran, M. Schuetz, and A. Hector. 2014. Eutrophication weakens stabilizing effects of diversity in natural grasslands. Nature 508:521.

Hautier, Y., E. Vojtech, and A. Hector. 2018. The importance of competition for light depends on productivity and disturbance. Ecology and Evolution 8:10655-10661.

Hillebrand, H., D. S. Gruner, E. T. Borer, M. E. S. Bracken, E. E. Cleland, J. J. Elser, W. S. Harpole, J. T. Ngai, E. W. Seabloom, J. B. Shurin, and J. E. Smith. 2007. Consumer versus resource control of producer diversity depends on ecosystem type and producer community structure. Proceedings of the National Academy of Sciences 104:10904-10909.

Hodgson, D., J. L. McDonald, and D. J. Hosken. 2015. What do you mean, "resilient"? Trends in Ecology and Evolution 30:503-506.

Hunter, M. D. 2001. Out of sight, out of mind: the impacts of root-feeding insects in natural and managed systems. Agricultural and Forest Entomology 3:3-9. 
Jongejans, E., and P. Schippers. 2001. Modeling seed dispersal by wind in herbaceous species. Page 215 Verhandlungen der Gesellschaft fur Okologie.

Kidd, J., P. Manning, J. Simkin, S. Peacock, and E. Stockdale. 2017. Impacts of 120 years of fertilizer addition on a temperate grassland ecosystem. PLOS ONE 12:e0174632.

Kohli, M., E. T. Borer, L. Kinkel, and E. W. Seabloom. 2019. Stability of grassland production is robust to changes in the consumer food web. Ecology Letters 22:707-716.

Körner, K., H. Pfestorf, F. May, and F. Jeltsch. 2014. Modelling the effect of belowground herbivory on grassland diversity. Ecological Modelling 273:79-85.

Kozlov, M. V., and E. L. Zvereva. 2017. Background Insect Herbivory: Impacts, Patterns and Methodology. Pages 313-355 Progress in Botany.

La Pierre, K. J., A. Joern, and M. D. Smith. 2015. Invertebrate, not small vertebrate, herbivory interacts with nutrient availability to impact tallgrass prairie community composition and forb biomass. Oikos 124:842-850.

Lamb, E. G., S. W. Kembel, and J. F. Cahill. 2009. Shoot, but not root, competition reduces community diversity in experimental mesocosms. Journal of Ecology 97:155-163.

Lambin, E. F., B. L. Turner, H. J. Geist, S. B. Agbola, A. Angelsen, J. W. Bruce, O. T. Coomes, R. Dirzo, G. Fischer, C. Folke, P. S. George, K. Homewood, J. Imbernon, R. Leemans, X. Li, E. F. Moran, M. Mortimore, P. S. Ramakrishnan, J. F. Richards, H. Skånes, W. Steffen, G. D. Stone, U. Svedin, T. A. Veldkamp, C. Vogel, and J. Xu. 2001. The causes of land-use and land-cover change: moving beyond the myths. Global Environmental Change 11:261269.

May, F., V. Grimm, and F. Jeltsch. 2009. Reversed effects of grazing on plant diversity: The role of below-ground competition and size symmetry. Oikos 118:1830-1843.

McSkimming, C., J. E. Tanner, B. D. Russell, and S. D. Connell. 2015. Compensation of nutrient pollution by herbivores in seagrass meadows. Journal of Experimental Marine Biology and Ecology 471:112-118.

Mortensen, B., B. Danielson, W. S. Harpole, J. Alberti, C. A. Arnillas, L. Biederman, E. T. Borer, M. W. Cadotte, J. M. Dwyer, N. Hagenah, Y. Hautier, P. L. Peri, and E. W. Seabloom. 2018. Herbivores safeguard plant diversity by reducing variability in dominance. Journal of Ecology 106:101-112.

Olff, H., and M. E. Ritchie. 1998. Effects of herbivores on grassland plant diversity. Trends in Ecology \& Evolution 13:261-265.

Pfestorf, H., K. Körner, I. Sonnemann, S. Wurst, and F. Jeltsch. 2016. Coupling experimental data with individual-based modelling reveals differential effects of root herbivory on 
grassland plant co-existence along a resource gradient. Journal of Vegetation Science 27:269-282.

Post, E. 2013. Erosion of community diversity and stability by herbivore removal under warming. Proceedings of the Royal Society B: Biological Sciences 280:2012272220122722.

Radchuk, V., F. De Laender, J. S. Cabral, I. Boulangeat, M. Crawford, F. Bohn, J. De Raedt, C. Scherer, J.-C. Svenning, K. Thonicke, F. M. Schurr, V. Grimm, and S. Kramer-Schadt. 2019. The dimensionality of stability depends on disturbance type. Ecology Letters 22:674684.

Rajaniemi, T. K. 2003. Explaining productivity-diversity relationships in plants. Oikos 101:449457.

Rajaniemi, T. K. 2003. Evidence for size asymmetry of belowground competition. Basic and Applied Ecology 4:239-247.

Rajaniemi, T. K., V. J. Allison, and D. E. Goldberg. 2003. Root competition can cause a decline in diversity with increased productivity. Journal of Ecology 91:407-416.

Raynaud, X., and P. W. Leadley. 2005. Symmetry of belowground competition in a spatially explicit model of nutrient competition. Ecological Modelling 189:447-453.

Reeg, J., S. Heine, C. Mihan, T. G. Preuss, S. McGee, and F. Jeltsch. 2018. Potential impact of effects on reproductive attributes induced by herbicides on a plant community. Environmental Toxicology and Chemistry 37:1707-1722.

Reeg, J., T. Schad, T. G. Preuss, A. Solga, K. Körner, C. Mihan, and F. Jeltsch. 2017. Modelling direct and indirect effects of herbicides on non-target grassland communities. Ecological Modelling 348:44-55.

Rewald, B., and C. Leuschner. 2009. Does root competition asymmetry increase with water availability? Plant Ecology \& Diversity 2:255-264.

Schwinning, S., and A. J. Parsons. 1999. The stability of grazing systems revisited: spatial models and the role of heterogeneity. Functional Ecology 13:737-747.

Schwinning, S., and J. Weiner. 1998. Mechanisms determining the degree of size asymmetry in competition among plants. Oecologia 113:447-455.

Sonnemann, I., H. Baumhaker, and S. Wurst. 2012. Species specific responses of common grassland plants to a generalist root herbivore (Agriotes spp. larvae). Basic and Applied Ecology 13:579-586. 
Sonnemann, I., S. Hempel, M. Beutel, N. Hanauer, S. Reidinger, and S. Wurst. 2013. The Root Herbivore History of the Soil Affects the Productivity of a Grassland Plant Community and Determines Plant Response to New Root Herbivore Attack. PLoS ONE 8:e56524.

Sonnemann, I., H. Pfestorf, F. Jeltsch, and S. Wurst. 2015. Community- Weighted Mean Plant Traits Predict Small Scale Distribution of Insect Root Herbivore Abundance. PLOS ONE 10:e0141148.

Steffen, W., K. Richardson, J. Rockstrom, S. E. Cornell, I. Fetzer, E. M. Bennett, R. Biggs, S. R. Carpenter, W. de Vries, C. A. de Wit, C. Folke, D. Gerten, J. Heinke, G. M. Mace, L. M. Persson, V. Ramanathan, B. Reyers, and S. Sorlin. 2015. Planetary boundaries: Guiding human development on a changing planet. Science 347:1259855-1259855.

Stein, C., S. B. Unsicker, A. Kahmen, M. Wagner, V. Audorff, H. Auge, D. Prati, and W. W. Weisser. 2010. Impact of invertebrate herbivory in grasslands depends on plant species diversity. Ecology 91:1639-1650.

Stevens, C. J., N. B. Dise, J. O. Mountford, and D. J. Gowing. 2004. Impact of Nitrogen Deposition on the Species Richness of Grasslands. Science 303:1876-1879.

Thebault, E., and C. Fontaine. 2010. Stability of Ecological Communities and the Architecture of Mutualistic and Trophic Networks. Science 329:853-856.

Vitousek, P. M. 1997. Human Domination of Earth's Ecosystems. Science 277:494-499.

Vogt, K. A., D. J. Vogt, P. A. Palmiotto, P. Boon, J. O’Hara, and H. Asbjornsen. 1995. Review of root dynamics in forest ecosystems grouped by climate, climatic forest type and species. Plant and Soil: An International Journal on Plant-Soil Relationships 187:159-219.

Weiher, E., A. van der Werf, K. Thompson, M. Roderick, E. Garnier, and O. Eriksson. 1999. Challenging Theophrastus: A common core list of plant traits for functional ecology. Journal of Vegetation Science 10:609-620.

Weiner, J., P. Stoll, H. Muller-Landau, and A. Jasentuliyana. 2001. The Effects of Density, Spatial Pattern, and Competitive Symmetry on Size Variation in Simulated Plant Populations. The American Naturalist 158:438-450.

Weiner, J. 1990. Asymmetric competition in plant populations. Trends in Ecology \& Evolution 5:360-364.

Weiner, J., and S. C. Thomas. 1986. Size Variability and Competition in Plant Monocultures. Oikos 47:211.

Weiner, J., D. B. Wright, and S. Castro. 1997. Symmetry of Below-Ground Competition between Kochia scoparia Individuals. Oikos 79:85. 
804 Weiss, L., and F. Jeltsch. 2015. The response of simulated grassland communities to the cessation of grazing. Ecological Modelling 303:1-11.

Weiss, L., L. Schalow, F. Jeltsch, and K. Geissler. 2019. Experimental evidence for root competition effects on community evenness in one of two phytometer species. Journal of Plant Ecology 12:281-291.

Wesche, K., B. Krause, H. Culmsee, and C. Leuschner. 2012. Fifty years of change in Central European grassland vegetation: Large losses in species richness and animal-pollinated plants. Biological Conservation 150:76-85.

812 Westoby, M., D. S. Falster, A. T. Moles, P. A. Vesk, and I. J. Wright. 2002. Plant Ecological Strategies: Some Leading Dimensions of Variation Between Species. Annual Review of

815 Wettberg, E. J. von, and J. Weiner. 2003. Larger Triticum aestivum plants do not preempt nutrient-rich patches in a glasshouse experiment. Plant Ecology 169:85-92.

Wiegand, T., F. Jeltsch, I. Hanski, and V. Grimm. 2003. Using pattern-oriented modeling for revealing hidden information: a key for reconciling ecological theory and application. Oikos 100:209-222.

Wijk, M. T. van, and W. Bouten. 2001. Towards understanding tree root profiles: simulating hydrologically optimal strategies for root distribution. Hydrology \& Earth System Sciences 5:629-644.

823 Wurst, S., and M. C. Rillig. 2011. Additive effects of functionally dissimilar above- and belowground organisms on a grassland plant community. Journal of Plant Ecology 4:221227. insect herbivory: A meta-analysis. Oecologia 169:441-452. 


\section{$828 \quad 10 \quad$ Tables}

829 Table 1: Impact of above- and belowground herbivory on the diversity response of simulated

830 grassland plots to eutrophication.

\begin{tabular}{|l|r|r|r|r|}
\hline \multicolumn{1}{|c|}{ Variable } & Estimate & \multicolumn{1}{c|}{ Std. Error } & t-value & \multicolumn{1}{c|}{ p-value } \\
\hline Intercept & 2.413 & 0.015 & 164.669 & $<\mathbf{0 . 0 0 1}$ \\
Eutrophication & -1.177 & 0.021 & -56.783 & $<\mathbf{0 . 0 0 1}$ \\
A1 & 0.522 & 0.021 & 25.188 & $<\mathbf{0 . 0 0 1}$ \\
B1 & -0.212 & 0.021 & -10.240 & $<\mathbf{0 . 0 0 1}$ \\
Eutrophication:A1 & 0.357 & 0.029 & 12.197 & $<\mathbf{0 . 0 0 1}$ \\
Eutrophication:B1 & -0.319 & 0.029 & -10.879 & $<\mathbf{0 . 0 0 1}$ \\
A1:B1 & 0.024 & 0.029 & 0.831 & 0.407 \\
Eutrophication:A1:B1 & -0.36 & 0.041 & -8.894 & $<\mathbf{0 . 0 0 1}$ \\
\hline Adjusted R-squared: $0.981 ;$ F-statistic: 2976 on 7 and 392 DF & \\
\hline
\end{tabular}


832 Table 2: Impact of above- and belowground herbivory removal on the resistance response of 833 simulated grassland plots to eutrophication.

\begin{tabular}{|l|r|r|r|r|}
\hline \multicolumn{1}{|c|}{ Variable } & \multicolumn{1}{c|}{ Estimate } & \multicolumn{1}{c|}{ Std. Error } & \multicolumn{1}{c|}{ t-value } & \multicolumn{1}{c|}{-value } \\
\hline Intercept & $1.199 \mathrm{e}-15$ & 0.026 & 0.000 & 1.000 \\
Eutrophication & -0.467 & 0.037 & -12.729 & $<\mathbf{0 . 0 0 1}$ \\
A0 & -0.131 & 0.037 & -3.578 & $<\mathbf{0 . 0 0 1}$ \\
B0 & 0.012 & 0.037 & 0.322 & 0.748 \\
Eutrophication:A0 & -0.134 & 0.052 & -2.588 & $<\mathbf{0 . 0 5}$ \\
Eutrophication:B0 & 0.171 & 0.052 & -2.588 & $<\mathbf{0 . 0 1}$ \\
A0:B0 & 0.040 & 0.052 & 0.768 & 0.443 \\
Eutrophication:A0:B0 & -0.149 & 0.073 & -2.035 & $<\mathbf{0 . 0 5}$ \\
\hline Adjusted R-squared: $0.692 ;$ F-statistic: 129.1 on 7 and 392 DF & & \\
\hline
\end{tabular}




\section{$83511 \quad$ Figures}

\section{$836 \quad 11.1 \quad$ Captions}

837 Figure 1. Shannon diversity after 100 years of experimental treatment. Control treatment retains

838 above- and belowground herbivory with ambient resource levels. A0 - Aboveground herbivory

839 removed, A1 - Aboveground herbivory present; B0 - Belowground herbivory removed, B1 -

840 Belowground herbivory present. While aboveground herbivory increases diversity, belowground

841 herbivory has a negative effect on diversity, exacerbating the negative effect of eutrophication.

843 Figure 2. Change in Shannon diversity (relative to the diversity with belowground herbivores

844 excluded) with increasing degree of belowground herbivore preference towards the largest plant

845 functional types. Aboveground herbivory is held constant and present. Ribbons indicate one

846 standard deviation around the mean. Preferentiality of root herbivores only slightly lessens the

847 negative effect of root herbivory on diversity. However, this is not sufficient to mitigate the

848 negative influence of eutrophication.

850 Figure 3. (A) Shoot uptake ratio and (B) root uptake ratio with experimental treatment. Each

851 ratio reflects the resources acquired per unit biomass. An increasing ratio indicates decreasing

852 competition for the respective resource. Boxplots are derived by averaging all plant-individuals'

853 per replicate, one simulation year before the experimental treatment terminates. A0 -

854 Aboveground herbivory removed, A1 - Aboveground herbivory present; B0 - Belowground

855 herbivory removed, B1 - Belowground herbivory present. While shoot herbivory decreases the

856 amount of competition aboveground, belowground herbivory mimics the influence of

857 eutrophication in shifting competition aboveground.

859 Figure 4. Resistance of Shannon diversity to the experimental treatment. Resistance is measured

860 as the change in Shannon diversity from the control diversity one year after the treatment begins.

861 The control diversity is defined as the treatment maintaining ambient belowground resources and

862 both above- and belowground herbivory. A0 - Aboveground herbivory removed, A1 -

863 Aboveground herbivory present; B0 - Belowground herbivory removed, B1 - Belowground

864 herbivory present. Notches indicate $95 \%$ confidence intervals of the medians. While 
865 aboveground competition increases the resistance of grasslands to eutrophication, belowground

866 herbivory decreases its effect.

867

868 Figure 5. Recovery of Shannon diversity after the experimental treatment. Recovery is measured

869 as the number of years required for Shannon diversity to return to and stay within $2 \sigma$ of its pre-

870 disturbance level for ten simulation years (time to return, TTR). The control is defined as the

871 treatment maintaining ambient belowground resources and both above- and belowground

872 herbivory. A0 - Aboveground herbivory removed, A1 - Aboveground herbivory present; B0 -

873 Belowground herbivory removed, B1 - Belowground herbivory present. Notches indicate 95\%

874 confidence intervals of the medians. 
bioRxiv preprint doi: https://doi.org/10.1101/799528; this version posted October 15,2019 . The copyright holder for this preprint (which was not certified by peer review) is the author/funder, who has granted bioRxiv a license to display the preprint in perpetuity. It is made available under aCC-BY-NC-ND 4.0 International license.

\section{$875 \quad \mathbf{1 1 . 2}$ Figure 1}

Ambient

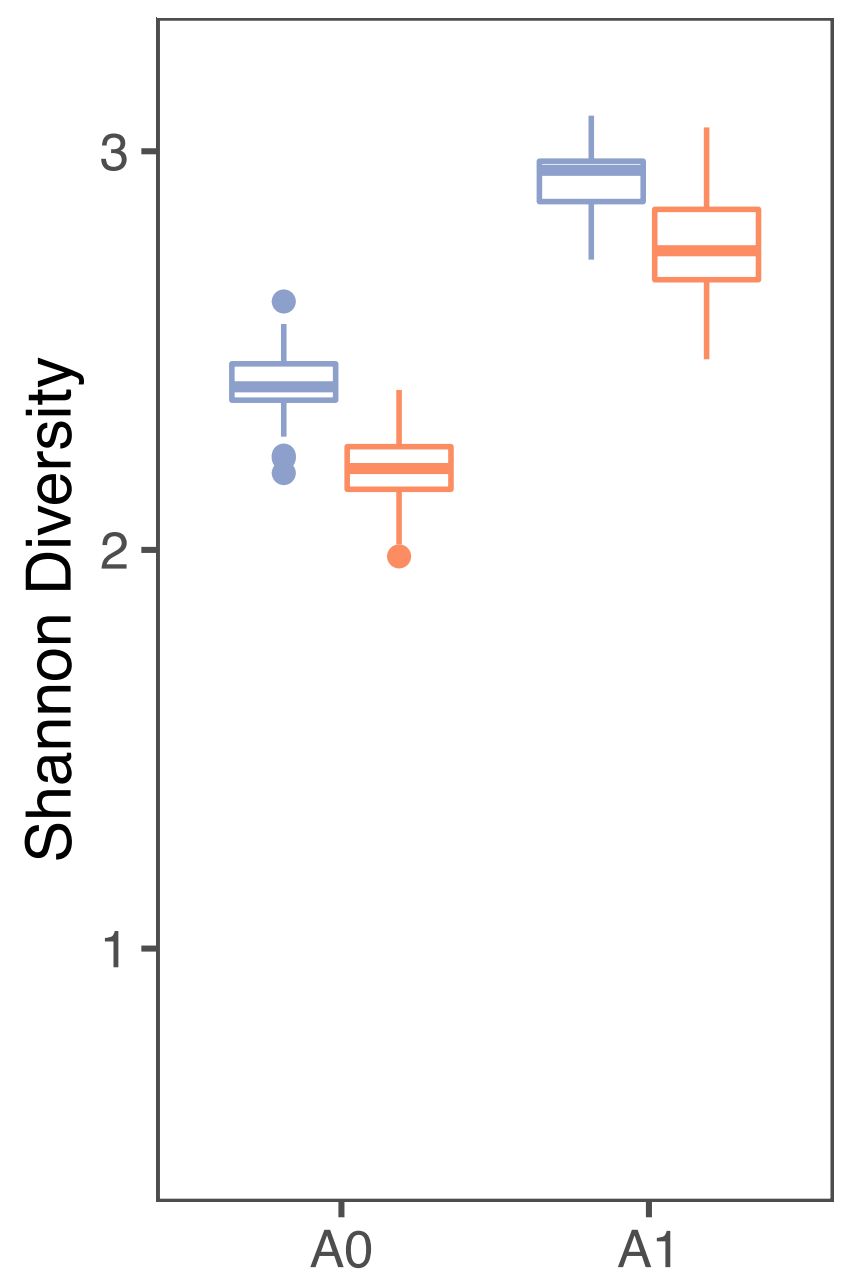

Eutrophic

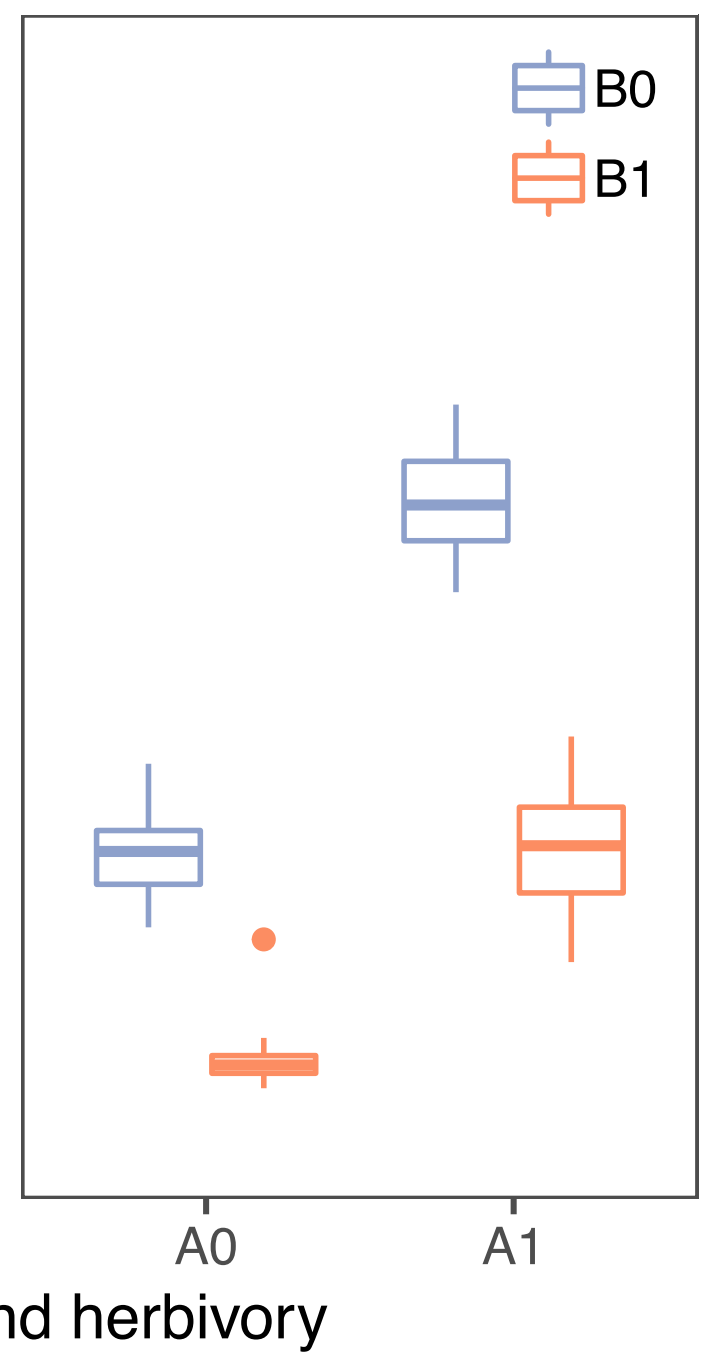

876

Aboveground herbivory 
bioRxiv preprint doi: https://doi.org/10.1101/799528; this version posted October 15,2019 . The copyright holder for this preprint (which was not certified by peer review) is the author/funder, who has granted bioRxiv a license to display the preprint in perpetuity. It is made available under aCC-BY-NC-ND 4.0 International license.

\subsection{Figure 2}

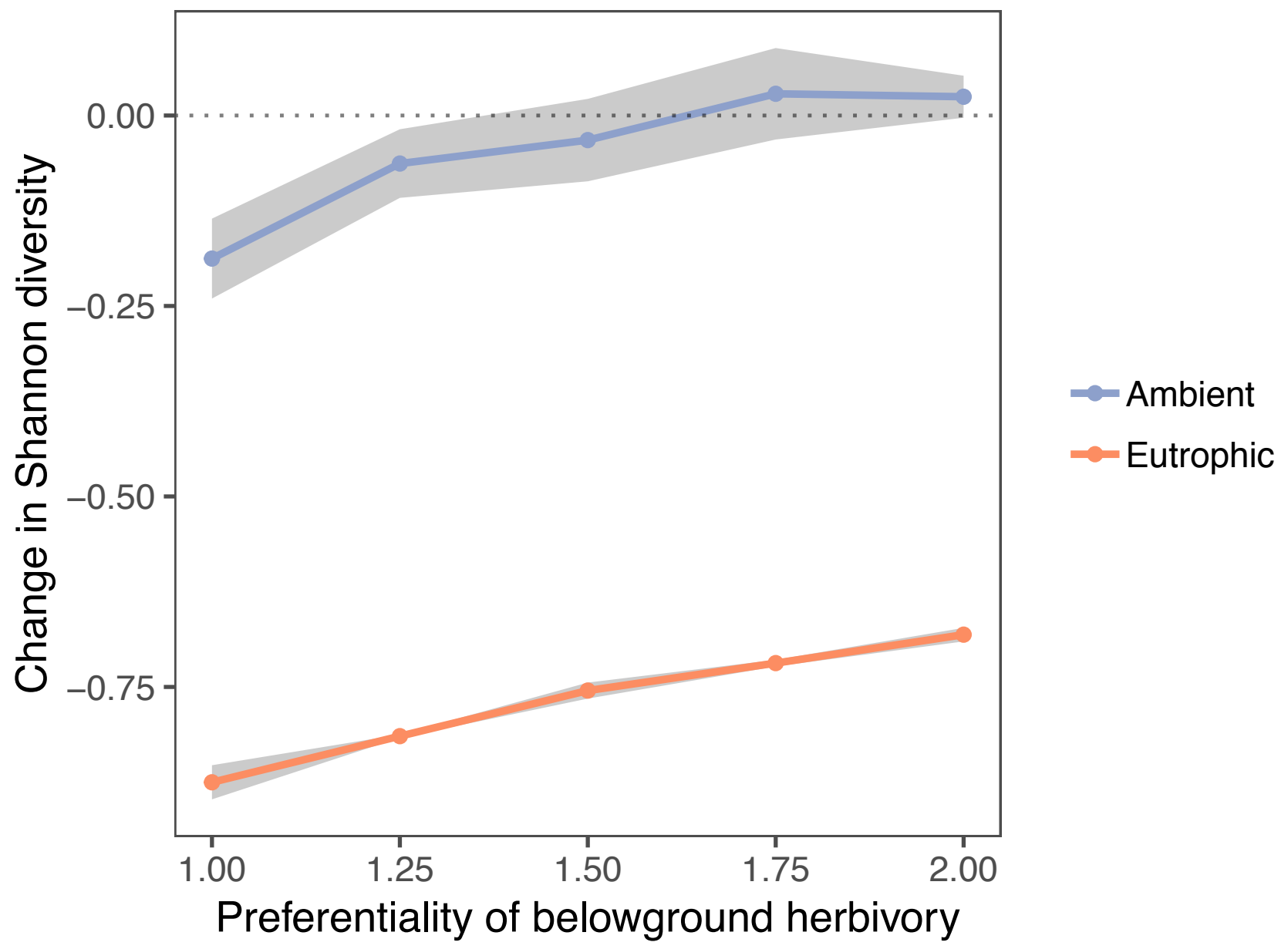

879

880 
bioRxiv preprint doi: https://doi.org/10.1101/799528; this version posted October 15,2019 . The copyright holder for this preprint (which was not certified by peer review) is the author/funder, who has granted bioRxiv a license to display the preprint in perpetuity. It is made available under aCC-BY-NC-ND 4.0 International license.

\section{$881 \quad 11.4 \quad$ Figure 3}

A

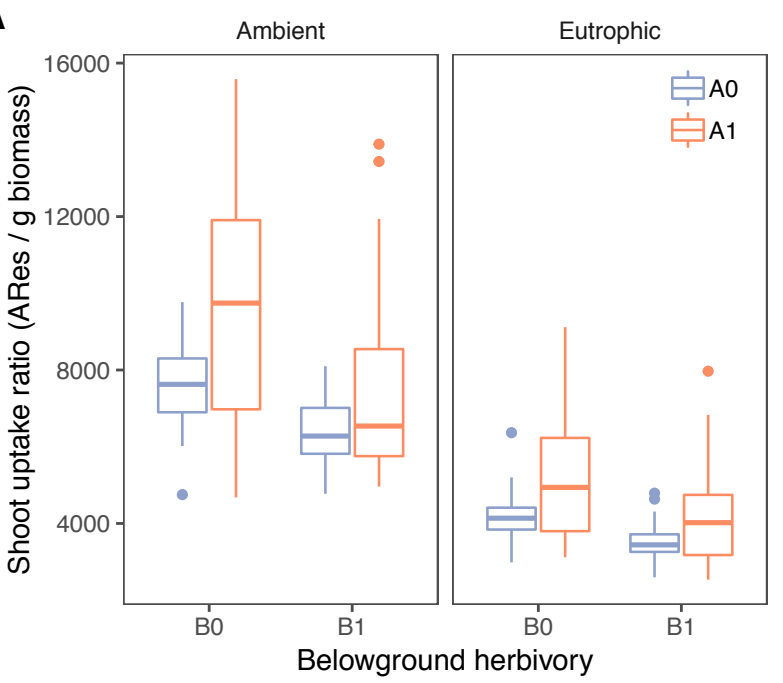

B

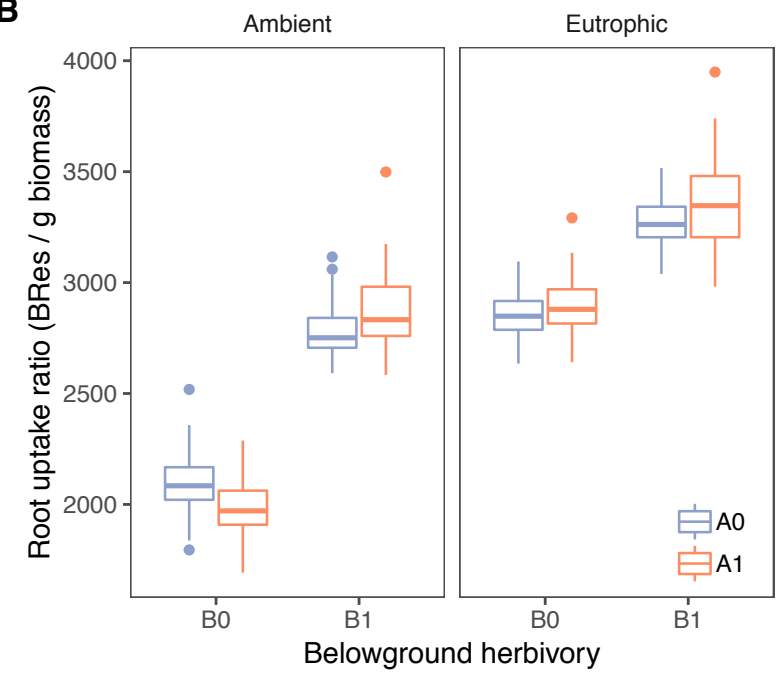

883 
bioRxiv preprint doi: https://doi.org/10.1101/799528; this version posted October 15,2019 . The copyright holder for this preprint (which was not certified by peer review) is the author/funder, who has granted bioRxiv a license to display the preprint in perpetuity. It is made available under aCC-BY-NC-ND 4.0 International license.

\section{$884 \quad 11.5 \quad$ Figure 4}

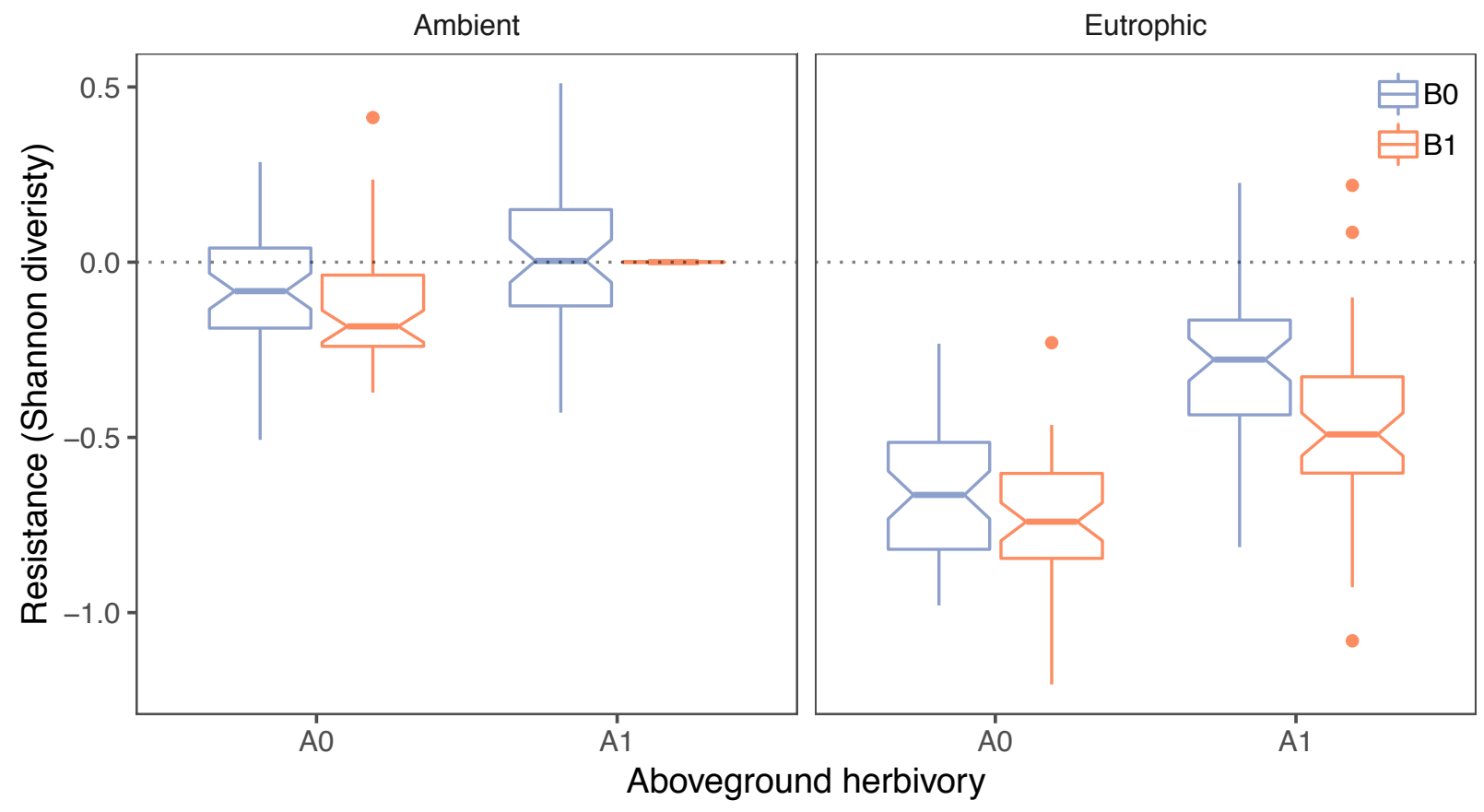

885

886 
bioRxiv preprint doi: https://doi.org/10.1101/799528; this version posted October 15,2019 . The copyright holder for this preprint (which was not certified by peer review) is the author/funder, who has granted bioRxiv a license to display the preprint in perpetuity. It is made available under aCC-BY-NC-ND 4.0 International license.

\section{$887 \quad 11.6 \quad$ Figure 5}

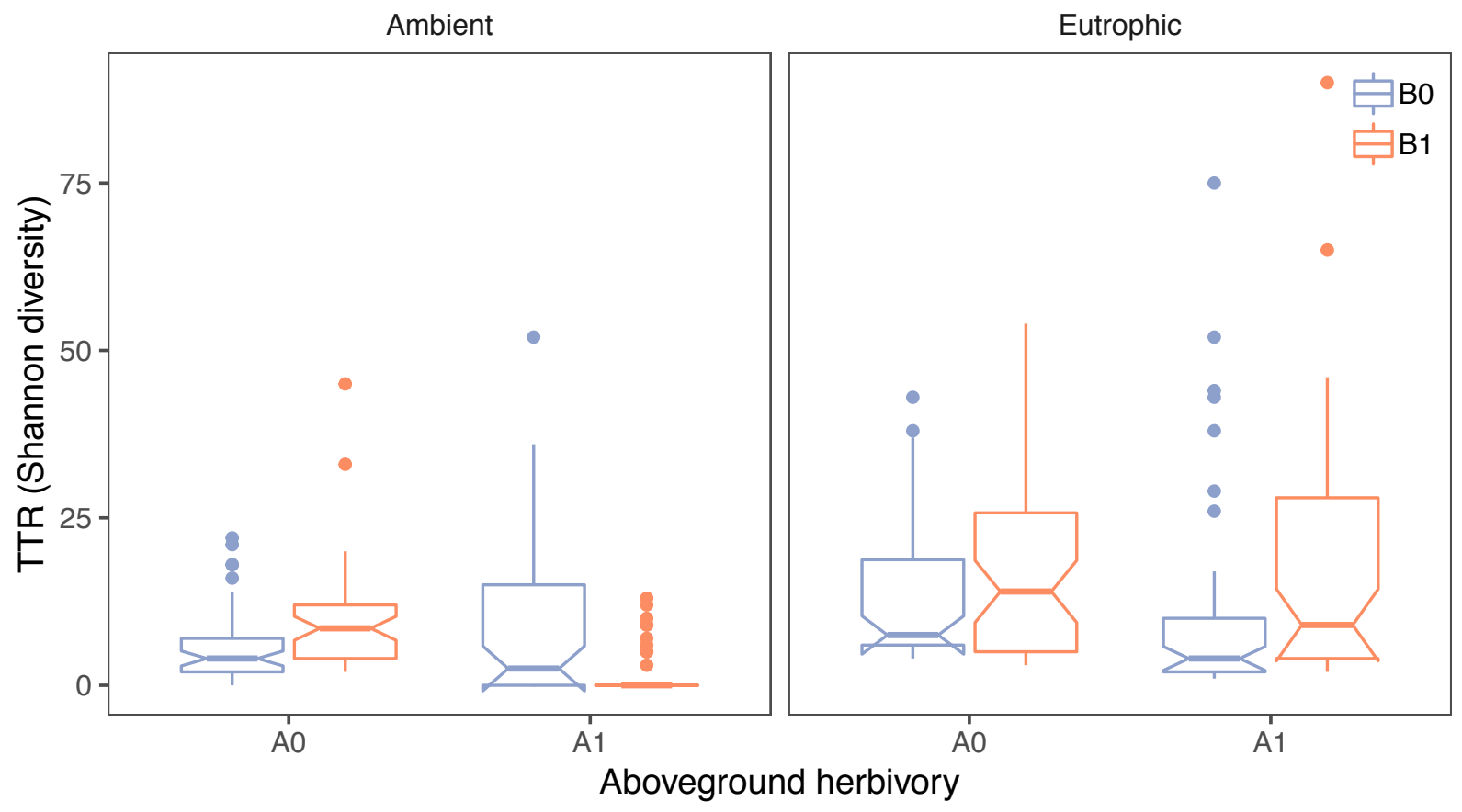

888 